\title{
ROLE OF NEW HERBICIDES IN DODDER (CUSCUTA CAMPESTRIS) CONTROL IN SUGAR BEET (BETA VULGARIS) FIELDS
}

\author{
HOSEYNI, S. M. ${ }^{1}-$ NAJAFI, H. ${ }^{2 *}-$ SANI, B. ${ }^{1}-$ MOZAFARI, H. ${ }^{1}$ \\ ${ }^{1}$ Department of Agronomy, Shahr-e-Qods Branch, Islamic Azad University, Tehran, Iran \\ ${ }^{2}$ Iranian Research Institute of Plant Protection, Agricultural Research, Education and \\ Extension Organization (AREEO), Tehran, Iran \\ *Corresponding author \\ e-mail: najafiamir@yahoo.com; phonelfax: +98-26-3270-5053
}

(Received 21 $1^{\text {st }}$ May 2018; accepted 31 Jul 2018)

\begin{abstract}
Dodder (Cuscuta campestris) control is a challenge and dodder is one of the factors limiting the cultivation of sugar beet in many regions of Iran. New herbicides can be useful in chemical control of dodder. This study was conducted to evaluate the effect of new mixture of herbicides on dodder control in sugar beet field. Results showed that the Propyzamide $\left(3 \mathrm{~L} \mathrm{ha}^{-1}\right)$ had the highest effect on dodder weed weight loss\% and this treatment led to $99.59 \%$ reduction in its fresh and dry weight. In addition, herbicide treatments were significant at 0.01 significance level within 15 and 30 days; after this time application of Propyzamide $3 \mathrm{~L} \mathrm{ha}^{-1}$ led to 90.63 and $100 \%$ reduction in dodder weed, respectively. The Propyzamide 3 $\mathrm{L} \mathrm{ha}^{-1}$ led to $80.63 \%$ increase in sugar beet foliage dry weight within 30 Days After Herbicide Application (DAHA). In addition, between treatments the highest increase percentage of sugar beet yield was obtained by Ethofumesate $\left(2 \mathrm{~L} \mathrm{ha}^{-1}\right)$ along with Gallant Supper $\left(1 \mathrm{~L} \mathrm{ha}^{-1}\right)$ and the removal of broad leaf about $86.55 \%$ compared to control. Totally, Propyzamide (1.9 $\left.\mathrm{L} \mathrm{ha}^{-1}\right)$ along with Gallant Supper $\left(0.75 \mathrm{~L} \mathrm{ha}^{-1}\right)$ showed the best results with the lowest dosages.
\end{abstract}

Keywords: chemical control, Ethofumesate, mixture herbicides, parasitic weed, Propyzamide

\section{Introduction}

It is believed that parasitic weeds have emerged as a serious challenge in agricultural production globally. Research show that roughly 20 families (3,000-5,000 species) of higher plants are parasitic in the plant kingdom. They are likely to inflict production losses of 30 $80 \%$ in main food and industrial crops around the world. Contrary to other weeds, conventional methods cannot control the parasitic weeds because of their life style. They mixed thoroughly with the host and their metabolic feature is strikingly similar to the host, which cannot be distinguished by treatments. Some of the parasites locate closely to the host root, which is hidden and cannot be detected until final are observed. Various approaches have been introduced including cultural, mechanical, chemical, use of resistant varieties, and biological to curb the negative effects of parasitic weeds; but most of them failed to achieve this aim.

One of the parasitic plant is field dodder, which is found on the stems and leaves of broadleaf plants, including weeds, field crops, vegetables, and ornamentals around the world. It is not easy to control field dodder because of close intimacy and interaction between the host and the parasite; thus, there must be herbicide that attacks the parasite without inflicting damage on the host (Sarić-Krsmanović and Vrbničanin, 2017).

Cuscuta campestris, also known as field dodder, has emerged as a widespread weed in several continents including Africa, Asia, Europe, Australia, and South America (Parker and Riches, 1993). All species of the genus Cuscuta receive their required mineral, water, and 
carbohydrates from their host plants because of the lake roots and leaves; besides some of the species of this genus are not able in terms of photosynthesis, including forage crops (especially alfalfa) and vegetables, some tree crops (grapevine, coffee), and ornamentals plants (Albert et al., 2008).

Dodder affects the growth and yield of the infected plants and it causes losses, which range from slight to complete destruction of the crop (Agrios, 1978 and Saric-Krsmanovic et al., 2017). Estimated yields sugar beet losses ranges are reduced by 3.5-4 $\mathrm{t} \mathrm{ha}^{-1}$ (Aly et al., 2003). Sarić-Krsmanović et al. (2015) conducted a study to investigate to see how glyphosate, propyzamide, imazethapyr, and diquat herbicides are able to curb field dodder in alfalfa of Pot and field trials in Novi Sad (location Rimski Šančevi) and in the field at Popovići (in the vicinity of Mladenovac). The highest effectiveness of $95 \%$ and $97.5 \%$, was reported by two glyphosate application rates (288 and $360 \mathrm{~g}$ a.i. ha) respectively.

If weed control is neglected, because of widely spaced rows and slow crop development in the early growing stages of sugar beet, up to 95\% yield disappears (Petersen, 2004). The reduced use of herbicides has become a necessity to limit environmental pollution and safeguard human health. Consequently, in the last years, the general trend was to achieve a gradual reduction in doses applied in pre and post-emergence using several blends of products to assess their synergic effects. The reduced use of herbicides can be obtained by replacing herbicide treatments with revaluation of agronomic techniques and minimizing the dose rate of herbicides (Cioni and Maines, 2010). Chemical control plays an important role in weed control in sugar beet production, until sugar beets become established; they are very susceptible to competition from weeds. That is one reason why many growers like to use preplant or pre-emergence herbicides. Early poste-mergence herbicide applications also help reduce competition from weeds while the sugar beets are small (Morishita, 2003). The most important herbicide mixtures contain the following active ingredients: metamitron, phenmedipham, desmedipham and ethofumesate (Vasel et al., 2012). Several studies have been conducted to evaluate the effects of herbicides on weeds. Longden (1989) reported that Weed beet did not affect the concentration of sugar (sucrose), potassium, sodium, $\alpha$ amino nitrogen, or invert sugar in the crop beets. Root and sugar yields were progressively reduced by increasing densities of weed beet.

The results of the study by Khaksar et al. (2017) showed that weed management had significant effect on root yield and sugar yield. Mean compared results illustrated that plots treated with chemical control and hand weeding were superior to control in terms of root yield and sugar yield with less impurity. Mekki (2016) evaluated treatments such as unweeding, one-hand hoeing, two-hand hoeing and chemical herbicide application (Acetochlor) at a rate of $0.750 \mathrm{~L} /$ feddan as pre-emergence, (one feddan $=0.42 \mathrm{ha}$ ) on weed control of sugar beet. Twice hand-hoeing resulted in a sharp decrease in total fresh and dry weights of weeds at 75 , 90 and 105 days after planting (DAP) and recording the highest root yield and its components in comparison with the other treatments. However, quality parameters were less affected using one or two-hand hoeing. Sharifi Ziveh et al. (2013) mentioned that consideration of the environmental negative effects of propyzamide and low environmental impact of ethofumesate herbicide is recommended for control dodder in the beet fields. The results of the study by Weinberg et al. (2003) showed that bleaching symptoms were observed in field dodder stems following the Flurochloridone, sulcotrione, and mesotrione treatments. Flurochloridone exerted its effects quickly; bleaching was observed in the stem 2 days after treatment (DAT) containing only $2 \% \beta$-carotene and having a considerable accumulation of phytoene in comparison with the control. Nevertheless, stem elongation was not prevented by Flurochloridone treatment. Full recovery of pigment composition at newly elongated stems 
was recorded 6 DAT; sulcotrione and mesotrione exerted similar effects Flurochloridone made the recovery take more time with less speed.

Many factors are responsible for reduced yield in sugar beet in Iran from which the most important factor is weed (Mansourian et al., 2016). Parasite weeds are competitive with the sugar beet crop for light, nutrients and water resources (Zimdahl, 1980). In addition, sugar beet seedlings are not able to compete well enough with weeds (Draycott, 2008). The aim of this research was to evaluate the effect of tank mixture of herbicides on Cuscuta spp in sugar beet field.

\section{Materials and methods}

\section{Study site and experimental design}

This research was conducted at the Research Farm of Iranian Research Institute of Plant Protection, in Meshkin-Dasht-e-Karaj, Alborz province, Iran. Geographical parameters of the site are the followings: latitude of $35^{\circ}$ and $41 \mathrm{~min}$, longitude of $51^{\circ}$ and $50 \mathrm{~min}$ east, height of $1200 \mathrm{~m}$ above sea level and its climate belongs to the semi-arid region in 2015.

This experiment was conducted in a randomized completed block design with 16 treatments and four replications (Table 1).

Table 1. Experimental treatments and rates

\begin{tabular}{|c|c|}
\hline \multicolumn{2}{|r|}{ The trial treatments } \\
\hline 1 & Propyzamide $\left(2 \mathrm{~L} \mathrm{ha}^{-1}\right)$ \\
\hline 2 & Propyzamide $\left(2.5 \mathrm{~L} \mathrm{ha}^{-1}\right)$ \\
\hline 3 & Propyzamide $\left(3 \mathrm{~L} \mathrm{ha}^{-1}\right)$ \\
\hline 4 & Ethofumesate $\left(1.5 \mathrm{~L} \mathrm{ha}^{-1}\right)$ \\
\hline 5 & Ethofumesate $\left(2 \mathrm{~L} \mathrm{ha}^{-1}\right)$ \\
\hline 6 & Ethofumesate $\left(2.5 \mathrm{~L} \mathrm{ha}^{-1}\right)$ \\
\hline 7 & Propyzamide $\left(2.5 \mathrm{~L} \mathrm{ha}^{-1}\right)+$ Betanal progress $\mathrm{OF}\left(3 \mathrm{~L} \mathrm{ha}^{-1}\right)+$ the removal of grass leaf \\
\hline 8 & Propyzamide $\left(2.5 \mathrm{~L} \mathrm{ha}^{-1}\right)+$ Gallant Supper $\left(1 \mathrm{~L} \mathrm{ha}^{-1}\right)+$ the removal of broad leaf \\
\hline 9 & Ethofumesate $\left(2 \mathrm{~L} \mathrm{ha}^{-1}\right)+$ Betanal progress $\mathrm{OF}\left(3 \mathrm{~L} \mathrm{ha}^{-1}\right)+$ the removal of grass leaf \\
\hline 10 & Ethofumesate $\left(2 \mathrm{~L} \mathrm{ha}^{-1}\right)+$ Gallant Supper $\left(1 \mathrm{~L} \mathrm{ha}^{-1}\right)+$ the removal of broad leaf \\
\hline 11 & Propyzamide $\left(1.9 \mathrm{~L} \mathrm{ha}^{-1}\right)+$ Betanal progress OF $\left(2.25 \mathrm{~L} \mathrm{ha}^{-1}\right)+$ the removal of grass leaf \\
\hline 12 & Propyzamide $\left(1.9 \mathrm{~L} \mathrm{ha}^{-1}\right)+$ Gallant Supper $\left(0.75 \mathrm{~L} \mathrm{ha}^{-1}\right)+$ the removal of broad leaf \\
\hline 13 & Ethofumesate $\left(1.5 \mathrm{~L} \mathrm{ha}^{-1}\right)+$ Betanal progress $\mathrm{OF}\left(2.25 \mathrm{~L} \mathrm{ha}^{-1}\right)+$ the removal of grass leaf \\
\hline 14 & Ethofumesate $\left(1.5 \mathrm{~L} \mathrm{ha}^{-1}\right)+$ Gallant Supper $\left(0.75 \mathrm{~L} \mathrm{ha}^{-1}\right)+$ the removal of broad leaf \\
\hline 15 & Betanal progress $\mathrm{OF}\left(3 \mathrm{~L} \mathrm{ha}^{-1}\right)+$ the removal of grass leaf \\
\hline 16 & Gallant Supper $\left(1 \mathrm{~L} \mathrm{ha}^{-1}\right)+$ the removal of broad leaf \\
\hline
\end{tabular}

The experimental plots were set to consist of $12 \mathrm{~m}^{2}$ ( $2 \mathrm{~m}$ in width and $6 \mathrm{~m}$ in length) including four planting lines $(50 \mathrm{~cm}$ width). Seed was cultivated with an appropriate depth of $2 \mathrm{~cm}$.

Each experimental plot was divided to two parts, in which $4 \mathrm{~m}^{2}$ from top side of each plot was considered as witness (without herbicides application). It should be mentioned that herbicides application were applied only in $8 \mathrm{~m}^{2}$ bottom down each experimental plot. Herbicides were applied when sugar beet was in two to four leaves stage (at the time of the complete attachment of the dodder to the host in each plot). Finally, the 
treatment assessments were in 15 and 30 day intervals after the application of herbicides.

For determination of dodder dry weight 30 days after treatment application, also to determine the total dry weight of weeds at the end of the growth season, they were collected by a $1 \times 1 \mathrm{~m}^{2}$ quadrature and placed in an oven for a period of one week at $75^{\circ} \mathrm{C}$ after transferring to the laboratory until their drying. After drying, they were weighed by digital scales. In addition, eye scoring according to the EWRC (European Weed Research Council), scale was performed to determine the effect of herbicide treatments. At the end of the growth period, the roots of sugar beet were harvested in each experimental plot; after washing and cutting off the limbs, weighed to determine the yield.

\section{Statistical analysis}

Analysis of variance and comparisons were conducted using SAS (Version 9.1) software. The mean comparison was carried out by using Duncan's multiple range tests. Differences were accepted as significant at $(P=0.05)$. Reporting of data as tables was conducted using Microsoft Excel 2016.

\section{Result and discussion}

\section{Dodder weight loss\%}

The results showed that the effect of treatments on weight of dodder weed was significant at $1 \%$ significance level (Table 2). According to the results obtained after 30 days of herbicides application, Propyzamide $\left(3 \mathrm{~L} \mathrm{ha}^{-1}\right)$ had the highest effect on dodder weed fresh weight and this treatment led to $99.59 \%$ reduction in comparison with control (Table 3). Also, Propyzamide (2.5 L ha $\left.{ }^{-1}\right)$, Propyzamide $\left(2 \mathrm{~L} \mathrm{ha}^{-1}\right)$, Propyzamide $\left(2.5 \mathrm{~L} \mathrm{ha}^{-1}\right)$ along with Betanal progress OF $\left(3 \mathrm{~L} \mathrm{ha}^{-1}\right)$ led to 99.5798 .47 and $97.08 .14 \%$ reduction in dodder weed fresh weight. Different herbicides in dodder control have been studied. Sohrabi et al. (2001) reported three herbicides of Trifluoralin, Ethofumesate and Propyzamide with $0.8,1.5$ and $1.6 \mathrm{~kg} \mathrm{ha}^{-1}$ respectively, Propizamide herbicide (1.6 $\mathrm{kg} \mathrm{ha}^{-1}$ ) reduced dodder density by $53 \%$ compared with control. Meighani et al. (2017) reported that Propizamide $2.5 \mathrm{~kg} \mathrm{ha}^{-1}$ with $57 \%$ reduction in dry weight of dodder was the best treatment compared to the control and there was no significant difference between Ethofumesate 2, and 2.5 $\mathrm{L} \mathrm{ha}^{-1}$ and Propyzamide 2 and $2.5 \mathrm{~L} \mathrm{ha}^{-1}$.

Table 2. Analysis of variance (MS) for the studied traits

\begin{tabular}{|c|c|c|c|c|c|c|c|c|}
\hline $\begin{array}{c}\text { Changed } \\
\text { source }\end{array}$ & D.F & $\begin{array}{c}\text { Dodder fresh } \\
\text { weight loss } \\
\text { (\%) } \\
\text { (30DAHA) }\end{array}$ & $\begin{array}{c}\text { Dodder dry } \\
\text { weight Loss } \\
(\%) \\
\text { (30DAHA) }\end{array}$ & $\begin{array}{c}\text { Dodder visual } \\
\text { weed control } \\
\text { rating } \\
\text { (15DAHA) }\end{array}$ & $\begin{array}{c}\text { Dodder visual } \\
\text { weed control } \\
\text { rating } \\
\text { (30DAHA) }\end{array}$ & $\begin{array}{c}\text { Total dry } \\
\text { weight of } \\
\text { weeds loss } \\
(\%) \\
\text { (30DAHA) } \\
\end{array}$ & 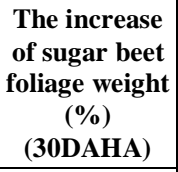 & $\begin{array}{l}\text { The increase } \\
\text { of sugar beet } \\
\text { yield }(\%)\end{array}$ \\
\hline Block & 3 & $1172.17 * *$ & $220.94^{\text {ns }}$ & 35 & $1432.47 * *$ & $1090.59^{\text {ns }}$ & $156.29^{\mathrm{ns}}$ & $548.29 * *$ \\
\hline Treatments & 15 & $1902.24 * *$ & $5186.18^{* *}$ & $981.77 * *$ & $3441.22 * *$ & $1234.06^{* *}$ & $148.21 *$ & $3392.02 * *$ \\
\hline Error & 45 & 122.93 & 195.23 & 259.11 & 147.14 & 155.78 & 55.58 & 27.81 \\
\hline C.V & & 13.75 & 20.45 & 22.64 & 16.69 & 15.06 & 8.44 & 8.97 \\
\hline
\end{tabular}

Ns, *,** show non-significant, significant effects at $5 \%$ statistically level and, significant effects at $1 \%$ statistically level, respectively 
Results of Dodder dry weight loss\% (30DAHA) showed that the highest losses (99.59\%) obtained by Propyzamide $3 \mathrm{~L} \mathrm{ha}^{-1}$ and this treatment showed no significant differences with Propyzamide $2.5 \mathrm{~L} \mathrm{ha}^{-1}$, Propyzamide $2 \mathrm{~L} \mathrm{ha}^{-1}$, Propyzamide $\left(2.5 \mathrm{~L} \mathrm{ha}^{-1}\right)$ along with Betanal progress OF $\left(3 \mathrm{~L} \mathrm{ha}^{-1}\right)$, Propyzamide $\left(2.5 \mathrm{~L} \mathrm{ha}^{-1}\right)$ along with Gallant Supper $\left(1 \mathrm{~L} \mathrm{ha}^{-1}\right)$, Ethoefumesate $2.5 \mathrm{~L} \mathrm{ha}^{-1}$, Ethofumesate $2 \mathrm{~L} \mathrm{ha}^{-1}$, Ethofumesate $1.5 \mathrm{~L} \mathrm{ha}^{-1}$, Ethofumesate $(2 \mathrm{~L}$ $\left.\mathrm{ha}^{-1}\right)$ along with Betanal progress OF $\left(3 \mathrm{~L} \mathrm{ha}^{-1}\right)$, Propyzamide $\left(1.9 \mathrm{~L} \mathrm{ha}^{-1}\right)$ along with Betanal progress OF (2.25 $\left.\mathrm{L} \mathrm{ha}^{-1}\right)$, Propyzamide $\left(1.9 \mathrm{~L} \mathrm{ha}^{-1}\right)$ along with Gallant Supper $\left(0.75 \mathrm{~L} \mathrm{ha}^{-1}\right)$ (Table 5).

\section{Dodder visual weed control rating according to the EWRC}

The results indicated that there is a significant difference between herbicide treatments in comparison with the control within 15 and 30 days after spraying $(\mathrm{P}<0.01)$. After 15 days from spraying, the application of Propyzamide $3 \mathrm{~L} \mathrm{ha}^{-1}$, Propyzamide $2.5 \mathrm{~L} \mathrm{ha}^{-1}$, Propyzamide $2 \mathrm{~L} \mathrm{ha}^{-1}$, Propyzamide $\left(2.5 \mathrm{~L} \mathrm{ha}^{-1}\right)$ along with Gallant Supper $1 \mathrm{~L} \mathrm{ha}^{-1}$ and the removal of broad leaf, Propyzamide $2.5 \mathrm{~L} \mathrm{ha}^{-1}$ along with Betanal progress OF L ha ${ }^{-1}$ and the removal of grass leaf, Propyzamide $1.9 \mathrm{~L} \mathrm{ha}^{-1}$ along with Gallant Supper $0.75 \mathrm{~L} \mathrm{ha}^{-1}$ and the removal of broad leaf led to $90.63,87.5,87.5,87.5$ and $84.38 \%$ reduction in dodder weed in comparison with the control (Tables 3 and 4). In the follow-up, after 30 days application of Propyzamide $3 \mathrm{~L} \mathrm{ha}^{-1}$, led to $100 \%$ reduction in dodder weed in comparison with control (Table 5); also, other treatments decreased the dodder weed and it was founded that Propyzamide $2.5 \mathrm{~L} \mathrm{ha}^{-1}$ caused $98.82 \%$ reduction.

Table 3. Herbicide efficacy of dodder control based on EWRC scaling method

\begin{tabular}{c|c|c}
\hline \multicolumn{2}{c}{ Weed reaction } \\
\hline Rating & Weed control $(\%)$ & Description (Wilkinson, 1971) \\
\hline 1 & 100 & Completely destroyed \\
2 & $99-96.5$ & Very good control \\
3 & $96.5-93$ & Good control \\
4 & $93-87.5$ & Satisfactory control \\
5 & $87.5-80$ & Just satisfactory control \\
6 & $80-70$ & Unsatisfactory control \\
7 & $70-50$ & Poor control \\
8 & $50-1$ & Very poor control \\
9 & 0 & As untreated \\
\hline
\end{tabular}

Table 4.1. Visual evaluation for herbicides efficacy on dodder weed control

\begin{tabular}{c|c|c}
\hline Herbicide treatments & $\begin{array}{c}\text { Visual weed control rating } \\
\text { after 15 days }\end{array}$ & $\begin{array}{c}\text { Visual weed control } \\
\text { rating after 30 days }\end{array}$ \\
\hline Propyzamide $3 \mathrm{~L} \mathrm{ha}^{-1}$ & ++++ & ++++ \\
Propyzamide $2.5 \mathrm{~L} \mathrm{ha}^{-1}$ & ++++ & ++++ \\
Propyzamide $2 \mathrm{~L} \mathrm{ha}^{-1}$ & ++++ & ++++ \\
Ethofumesate $2.5 \mathrm{~L} \mathrm{ha}^{-1}$ & +++ & ++++ \\
Ethofumesate $1.5 \mathrm{~L} \mathrm{ha}^{-1}$ & ++ & +++ \\
Ethofumesate $2 \mathrm{~L} \mathrm{ha}^{-1}$ & ++ & ++ \\
Betanal progress OF $\left(3 \mathrm{~L} \mathrm{ha}^{-1}\right)$ & ++ & - \\
Gallant Supper $\left(1 \mathrm{~L} \mathrm{ha}^{-1}\right)$ & ++ & - \\
\hline
\end{tabular}


Table 4.2. Visual evaluation for mixture herbicides efficacy on dodder weed control

\begin{tabular}{|c|c|c|}
\hline Herbicide treatments & $\begin{array}{l}\text { Visual weed } \\
\text { control rating } \\
\text { after } 15 \text { days }\end{array}$ & $\begin{array}{l}\text { Visual weed } \\
\text { control rating } \\
\text { after } 30 \text { days }\end{array}$ \\
\hline Propyzamide $\left(2.5 \mathrm{~L} \mathrm{ha}^{-1}\right)+$ Gallant Supper $\left(1 \mathrm{~L} \mathrm{ha}^{-1}\right)$ & ++++ & ++++ \\
\hline Propyzamide $\left(2.5 \mathrm{~L} \mathrm{ha}^{-1}\right)+$ Betanal progress OF $\left(3 \mathrm{~L} \mathrm{ha}^{-1}\right)$ & ++++ & ++++ \\
\hline Propyzamide $\left(1.9 \mathrm{~L} \mathrm{ha}^{-1}\right)+$ Gallant Supper $\left(0.75 \mathrm{~L} \mathrm{ha}^{-1}\right)$ & +++ & ++++ \\
\hline Propyzamide $\left(1.9 \mathrm{~L} \mathrm{ha}^{-1}\right)+$ Betanal progress OF $\left(2.25 \mathrm{~L} \mathrm{ha}^{-1}\right)$ & +++ & +++ \\
\hline Ethofumesate $\left(2 \mathrm{~L} \mathrm{ha}^{-1}\right)+$ Gallant Supper $\left(1 \mathrm{~L} \mathrm{ha}^{-1}\right)$ & ++ & ++ \\
\hline Ethofumesate $\left(2 \mathrm{~L} \mathrm{ha}^{-1}\right)+$ Betanal progress $\mathrm{OF}\left(3 \mathrm{~L} \mathrm{ha}^{-1}\right)$ & ++ & ++ \\
\hline Ethofumesate $\left(1.5 \mathrm{~L} \mathrm{ha}^{-1}\right)+$ Gallant Supper $\left(0.75 \mathrm{~L} \mathrm{ha}^{-1}\right)$ & ++ & + \\
\hline Ethofumesate $\left(1.5 \mathrm{~L} \mathrm{ha}^{-1}\right)+$ Betanal progress OF $\left(2.25 \mathrm{~L} \mathrm{ha}^{-1}\right)$ & ++ & + \\
\hline
\end{tabular}

Controlled more than $85 \%:++++$

Controlled 70 to $85 \%:+++$

Controlled 50 to $70 \%:++$

Controlled 30 to $50 \%:+$

Controlled below $30 \%$ : -

\section{Total dry weight of weed loss (\%)}

According to results Ethofumesate $\left(2 \mathrm{~L} \mathrm{ha}^{-1}\right)$ along with Betanal progress OF (3 L ha $\left.{ }^{1}\right)$ and Ethofumesate $\left(2 \mathrm{~L} \mathrm{ha}^{-1}\right)$ along with Gallant Supper $\left(1 \mathrm{~L} \mathrm{ha}^{-1}\right)$ led to 76.25 and $76.33 \%$ reduction in herbs dry weight, respectively. In addition, it was found that Propyzamide $2 \mathrm{~L} \mathrm{ha}^{-1}$ treatment had the lowest effect on herbs dry weight control. SarićKrsmanović et al. (2015) reported that using propyzamide (1500 and $2000 \mathrm{~g}$ a.i. ha) was not effective enough ( $85 \%$ and $87 \%$, respectively).

The increase of sugar beet root yield and sugar beet foliage weight according to the results of this study, herbicide treatments had significant effect on root yield at $1 \%$ probability level (Table 2), between treatments the highest yield mean was obtained by Ethofumesate $\left(2 \mathrm{~L} \mathrm{ha}^{-1}\right)$ along with Gallant Supper $\left(1 \mathrm{~L} \mathrm{ha}^{-1}\right)$ and the removal of broad leaf, which means about $88.55 \%$ increase compared to control. Also other treatments increased root yield through weed control, Ethofumesate $\left(2.5 \mathrm{~L} \mathrm{ha}^{-1}\right)$ along with Gallant Supper $\left(1 \mathrm{~L} \mathrm{ha}^{-1}\right)$ and the removal of broad leaf, Propyzamide $\left(2.5 \mathrm{~L} \mathrm{ha}^{-1}\right)$ along with Gallant Supper $\left(1 \mathrm{~L} \mathrm{ha}^{-1}\right)$, Gallant Supper $\left(1 \mathrm{~L} \mathrm{ha}^{-1}\right)$, Betanal progress OF $\left(3 \mathrm{~L} \mathrm{ha}^{-1}\right)$, Propyzamide (1.9 $\left.\mathrm{L} \mathrm{ha}^{-1}\right)$ along with Gallant Supper $\left(0.75 \mathrm{~L} \mathrm{ha}^{-1}\right)$, Ethofumesate $(1.5 \mathrm{~L}$ $\left.\mathrm{ha}^{-1}\right)$ along with Gallant Supper $\left(0.75 \mathrm{~L} \mathrm{ha}^{-1}\right)$ and Ethofumesate $\left(2 \mathrm{~L} \mathrm{ha}^{-1}\right)$ along with Betanal progress OF $\left(3 \mathrm{~L} \mathrm{ha}^{-1}\right)$ resulted in $85.66 \%, 84.95 \%, 84.79 \%, 84.67 \%, 78.59 \%$ and $78.03 \%$, respectively in comparison with the control. The lowest increase in yield was obtained by Propyzamide $2 \mathrm{~L} \mathrm{ha}^{-1}$ by $18.2 \%$ in comparison with control (Table 5). Also, it was founded that Propyzamide $\left(2.5 \mathrm{~L} \mathrm{ha}^{-1}\right)$ along with Gallant Supper $\left(1 \mathrm{~L} \mathrm{ha}^{-1}\right)$ and Propyzamide $\left(2.5 \mathrm{~L} \mathrm{ha}^{-1}\right)$ along with Betanal progress OF $\left(3 \mathrm{~L} \mathrm{ha}^{-1}\right)$ treatments led to 93.96 and $93.97 \%$ increase of sugar beet leaf weight as the highest effects, respectively. In this regard, the effect of some herbicide treatments were studied on dodder fresh and dry weight and sugar beet yield by Meighani et al. (2017); their results indicated Propyzamide Burst $2.5 \mathrm{~L} \mathrm{ha}^{-1}$ as the best herbicide treatment and causing the highest decrease in dodder fresh and dry weight (93 to 99\%, compared to dodder infested control). Based on field studies of these researchers, Propyzamide Burst 2 to 2.5 $\mathrm{L} \mathrm{ha}^{-1}$ and ethofumesate $2.5 \mathrm{~L} \mathrm{ha}^{-1}$ were the best treatments. Since SC formulation is 
safer and easier to apply than WP formulation, Propyzamide Burst 2 to $2.5 \mathrm{~L} \mathrm{ha}^{-1}$ and ethofumesate $2.5 \mathrm{~L} \mathrm{ha}^{-1}$ are recommended for dodder control in sugar beet.

Table 5.1. The effect of herbicide treatments on the percentage means of dodder fresh and dry weight loss, increasing sugar beet foliage dry weight and sugar beet increasing yield compared to the control with dodder

\begin{tabular}{|c|c|c|c|c|c|c|c|}
\hline Treatments & \begin{tabular}{|c|} 
Dodder \\
fresh \\
weight \\
loss (\%) \\
(30DAHA)
\end{tabular} & $\begin{array}{c}\text { Dodder dry } \\
\text { weight loss } \\
(\%) \\
\text { (30DAHA) }\end{array}$ & $\begin{array}{c}\text { Dodder } \\
\text { visual weed } \\
\text { control } \\
\text { rating } \\
\text { (15DAHA) }\end{array}$ & $\begin{array}{c}\text { Dodder } \\
\text { visual weed } \\
\text { control } \\
\text { rating } \\
\text { (30DAHA) }\end{array}$ & $\begin{array}{c}\text { Total dry } \\
\text { weight of } \\
\text { weeds loss } \\
(\%) \\
\text { (30DAHA) }\end{array}$ & $\begin{array}{c}\text { The increase } \\
\text { of sugar beet } \\
\text { foliage dry } \\
\text { weight }(\%) \\
\text { (30DAHA) }\end{array}$ & $\begin{array}{c}\text { The } \\
\text { increase } \\
\text { of sugar } \\
\text { beet yield } \\
(\%)\end{array}$ \\
\hline Propyzamide $3 \mathrm{~L} \mathrm{ha}^{-1}$ & $99.59 \mathrm{a}$ & $99.59 \mathrm{a}$ & $90.63 a$ & $100 \mathrm{a}$ & $40.74 \mathrm{c}$ & $80.63 b$ & $26.11 \mathrm{de}$ \\
\hline Propyzamide $2.5 \mathrm{~L} \mathrm{ha}^{-1}$ & $99.57 \mathrm{a}$ & $98.65 \mathrm{a}$ & $87.5 \mathrm{a}$ & $98.82 \mathrm{a}$ & $38.83 \mathrm{c}$ & $80.36 \mathrm{~b}$ & $25.62 \mathrm{de}$ \\
\hline Propyzamide $2 \mathrm{~L} \mathrm{ha}^{-1}$ & $98.47 \mathrm{a}$ & $97.5 \mathrm{a}$ & $87.5 \mathrm{a}$ & $98.82 \mathrm{a}$ & $38.49 \mathrm{c}$ & $80.29 b$ & $18.2 \mathrm{e}$ \\
\hline Ethofumesate $2.5 \mathrm{~L} \mathrm{ha}^{-1}$ & $95.2 \mathrm{ab}$ & $80.14 \mathrm{ab}$ & $71.88 \mathrm{abc}$ & $92.13 \mathrm{a}$ & $43.66 \mathrm{c}$ & $81.43 b$ & $27.8 \mathrm{~d}$ \\
\hline Ethofumesate $2 \mathrm{~L} \mathrm{ha}^{-1}$ & $94.01 \mathrm{ab}$ & $89.5 \mathrm{ab}$ & $65.63 \mathrm{abc}$ & $79.8 \mathrm{ab}$ & $41.69 \mathrm{c}$ & $81.1 b$ & $20.72 \mathrm{de}$ \\
\hline Ethofumesate $1.5 \mathrm{~L} \mathrm{ha}^{-1}$ & $92.11 \mathrm{ab}$ & $89.3 \mathrm{ab}$ & $68.75 \mathrm{abc}$ & $83.21 \mathrm{ab}$ & $41.17 \mathrm{c}$ & $80.98 b$ & $19.02 \mathrm{e}$ \\
\hline Betanal progress $\mathrm{OF}\left(3 \mathrm{~L} \mathrm{ha}^{-1}\right)$ & 49.64de & $9.05 \mathrm{~d}$ & $50 \mathrm{c}$ & $21.8 \mathrm{c}$ & $75.49 \mathrm{a}$ & $92.65 \mathrm{ab}$ & $84.79 \mathrm{ab}$ \\
\hline Gallant Supper $\left(1 \mathrm{~L} \mathrm{ha}^{-1}\right)$ & $34.32 \mathrm{e}$ & $9.32 \mathrm{~d}$ & $50 \mathrm{c}$ & $23.61 \mathrm{c}$ & $75.91 \mathrm{a}$ & $91.74 \mathrm{ab}$ & $84.95 \mathrm{ab}$ \\
\hline
\end{tabular}

Means, in each column, followed by at least one letter in common are not significantly different at the $1 \%$ probability level using Duncan's multiple-range test

Table 5.2. The effect of mixture herbicide treatments on the percentage means of dodder fresh and dry weight loss, increasing sugar beet foliage dry weight and sugar beet increasing yield compared to the control with dodder

\begin{tabular}{|c|c|c|c|c|c|c|c|}
\hline Treatments & $\begin{array}{c}\text { Dodder fresh } \\
\text { weight loss } \\
(\%) \\
\text { (30DAHA) }\end{array}$ & $\begin{array}{c}\text { Dodder dry } \\
\text { weight loss } \\
(\%) \\
\text { (30DAHA) }\end{array}$ & $\begin{array}{c}\text { Dodder } \\
\text { visual weed } \\
\text { control } \\
\text { rating } \\
\text { (15DAHA) }\end{array}$ & $\begin{array}{c}\text { Dodder } \\
\text { visual weed } \\
\text { control } \\
\text { rating } \\
\text { (30DAHA) }\end{array}$ & $\begin{array}{c}\text { Total dry } \\
\text { weight of } \\
\text { weeds loss } \\
(\%) \\
\text { (30DAHA) }\end{array}$ & $\begin{array}{c}\text { The increase } \\
\text { of sugar beet } \\
\text { foliage dry } \\
\text { weight (\%) } \\
\text { (30DAHA) }\end{array}$ & $\begin{array}{c}\text { The increase } \\
\text { of sugar beet } \\
\text { yield }(\%)\end{array}$ \\
\hline $\begin{array}{c}\text { Propyzamide }\left(2.5 \mathrm{~L} \mathrm{ha}^{-1}\right) \\
+ \text { Betanal progress OF } \\
\left(3 \mathrm{~L} \mathrm{ha}^{-1}\right)\end{array}$ & $97.08 \mathrm{a}$ & $93.85 \mathrm{a}$ & $87.5 \mathrm{a}$ & $98.82 \mathrm{a}$ & $51.07 \mathrm{bc}$ & $93.73 a$ & $76.86 b c$ \\
\hline $\begin{array}{c}\text { Propyzamide }\left(2.5 \mathrm{~L} \mathrm{ha}^{-1}\right) \\
+ \text { Gallant Supper } \\
\left(1 \mathrm{~L} \mathrm{ha}^{-1}\right)\end{array}$ & $95.82 \mathrm{ab}$ & $96.56 \mathrm{a}$ & $87.5 \mathrm{a}$ & $91.44 \mathrm{a}$ & $76.26 \mathrm{a}$ & $93.96 \mathrm{a}$ & $85.66 \mathrm{a}$ \\
\hline $\begin{array}{l}\text { Ethofumesate }\left(2 \mathrm{~L} \mathrm{ha}^{-1}\right) \\
+ \text { Betanal progress OF } \\
\left(3 \mathrm{~L} \mathrm{ha}^{-1}\right)\end{array}$ & $78.59 b c$ & $69.39 \mathrm{ab}$ & $65.25 \mathrm{abc}$ & $65.62 b$ & $76.25 \mathrm{a}$ & $93.86 \mathrm{a}$ & $78.03 \mathrm{abc}$ \\
\hline $\begin{array}{l}\text { Ethofumesate }\left(2 \mathrm{~L} \mathrm{ha}^{-1}\right) \\
+ \text { Gallant Supper } \\
\left(1 \mathrm{~L} \mathrm{ha}^{-1}\right)\end{array}$ & $72.68 \mathrm{c}$ & $56.49 \mathrm{c}$ & $65.63 \mathrm{abc}$ & $65.43 b$ & $76.33 a$ & $94.18 \mathrm{a}$ & $86.55 a$ \\
\hline $\begin{array}{c}\text { Propyzamide }\left(1.9 \mathrm{~L} \mathrm{ha}^{-1}\right) \\
+ \text { Betanal progress OF } \\
\left(2.25 \mathrm{~L} \mathrm{ha}^{-1}\right)\end{array}$ & $84.05 \mathrm{ab}$ & $84.23 \mathrm{ab}$ & $81.25 \mathrm{ab}$ & $90.27 \mathrm{a}$ & $51.42 b c$ & $91.71 \mathrm{ab}$ & $71.35 \mathrm{c}$ \\
\hline $\begin{array}{c}\text { Propyzamide }\left(1.9 \mathrm{~L} \mathrm{ha}^{-1}\right) \\
+ \text { Gallant Supper } \\
\left(0.75 \mathrm{~L} \mathrm{ha}^{-1}\right)\end{array}$ & $95.02 \mathrm{ab}$ & $93.64 \mathrm{a}$ & $84.37 \mathrm{a}$ & $91.01 \mathrm{a}$ & $56.41 \mathrm{abc}$ & $91.21 \mathrm{ab}$ & $84.67 \mathrm{ab}$ \\
\hline $\begin{array}{c}\text { Ethofumesate }\left(1.5 \mathrm{~L} \mathrm{ha}^{-1}\right) \\
+ \text { Betanal progress OF } \\
\left(2.25 \mathrm{~L} \mathrm{ha}^{-1}\right)\end{array}$ & $50.37 \mathrm{de}$ & $14.82 \mathrm{~d}$ & $50 \mathrm{c}$ & $31.49 \mathrm{c}$ & $68.66 \mathrm{ab}$ & $91.56 \mathrm{ab}$ & $70.84 \mathrm{c}$ \\
\hline $\begin{array}{c}\text { Ethofumesate }\left(1.5 \mathrm{~L} \mathrm{ha}^{-1}\right) \\
+ \text { Gallant Supper } \\
\left(0.75 \mathrm{~L} \mathrm{ha}^{-1}\right)\end{array}$ & $52.97 \mathrm{abc}$ & $10.62 d$ & $53.13 \mathrm{c}$ & $30.53 c$ & $72.03 \mathrm{ab}$ & $93.7 \mathrm{a}$ & 78.59abc \\
\hline
\end{tabular}

Means, in each column, followed by at least one letter in common are not significantly different at the $1 \%$ probability level using Duncan's multiple-range test 


\section{Conclusion}

According to the results of the present study, Propyzamide $\left(3 \mathrm{~L} \mathrm{ha}^{-1}\right)$ had the highest effect on dodder weed weight. After 15 and 30 days from spraying, the application of Propyzamide $3 \mathrm{~L} \mathrm{ha}^{-1}$ led to 90.63 and $100 \%$ reduction in dodder weed, respectively in comparison with control. Accordingly, Propyzamide $\left(2.5 \mathrm{~L} \mathrm{ha}^{-1}\right)$ along with Gallant Supper $\left(1 \mathrm{~L} \mathrm{ha}^{-1}\right)$ and Propyzamide $\left(2.5 \mathrm{~L} \mathrm{ha}^{-1}\right)$ along with Betanal progress OF (3 L ha $\left.{ }^{-1}\right)$ treatments demonstrated the best visual weed control ratings after both periods. In addition, between treatments the highest yield mean was obtained by Ethofumesate $(2 \mathrm{~L}$ $\left.\mathrm{ha}^{-1}\right)$ along with Gallant Supper $\left(1 \mathrm{~L} \mathrm{ha}^{-1}\right)$ and the removal of broad leaf. Gallant Supper treatment illustrated the highest effect on sugar beet yield $(84.95 \%)$ compared to Betanal progress. Although different dosages of Propyzamide (2, 2.5, and $3 \mathrm{~L} \mathrm{ha}^{-1}$ ) showed better control on dodder fresh and dry weight loss, but sugar beet yield is not affected by specific weed and vast range of weeds are effective on sugar beet yield. Therefore, it sounds that tank mixture of herbicides such as Propyzamide along with Gallant Supper led to suitable control of most weeds and increase of sugar beet yield. Totally, according to the aims of this research, which was reduced use of herbicides by tank mixture of herbicides together, Propyzamide $\left(1.9 \mathrm{~L} \mathrm{ha}^{-1}\right)$ along with Gallant Supper $\left(0.75 \mathrm{~L} \mathrm{ha}^{-1}\right)$ showed the best results with the lowest dosages.

\section{REFERENCES}

[1] Agrios, G. N. (1978): Plant Pathology. 2nd ed. - Academic Press, New York, pp. 466470 .

[2] Albert, M., Belastegui-Macadam, X., Bleischwitz, M., Kaldenhoff, R. (2008): Cuscuta spp: Parasitic Plants in the Spotlight of Plant Physiology, Economy, and Ecology. - In: Luttge, U., Beyschlag, W., Murata, J. (eds.) Progress in Botany. Springer, Heidelberg, pp. 267-277.

[3] Aly, R. (2007): Conventional and biotechnological approaches for control of parasitic weeds. - In Vitro Cellular and Developmental Biology-Plant 43(4): 304-317.

[4] Aly, R., Westwood, J., Cramer, C. (2003): Crop protection against parasites/pathogens through expression of sarcotoxin-like peptide. - Patent No. WO02094008.

[5] Cioni, F., Maines, G. (2010): Weed control in sugarbeet. - Sugar Technology 2(3-4): 243-255.

[6] Draycott, A. P. (2008): Sugar Beet. - Wiley, New York.

[7] Khaksar, K., Noghabi, M. A., Sharifabad, H. H., Majidi, E., Normohammadi, G. (2017): Effects of tillage timing, cover crop and weed control methods on sugar beet yield and quality. - Crop Research 52: 970-4884.

[8] Longden, P. C. (1989): Effects of increasing weed-beet density on sugar-beet yield and quality. - Annals of Applied Biology 114(3): 527-532.

[9] Mansourian, S., Izadi Darbandi, E., Rashed Mohassel, M. H., Rastgo, M., Kanouni, H. (2016): Comparison of artificial neural networks and logistic regression as potential methods for predicting weed populations on dryland chickpea and winter wheat fields of Kurdistan province, Iran. - Crop Protection 93: 43-51.

[10] Meighani, F., Nezamabadi, N., Karaminejad, M., Jafarzadeh, N. (2017): Investigating efficacy of new herbichdes to control dodder (Cuscuta campestris) in sugarbeet (Beta vulgaris) fields. - Journal of Weed Science 12: 199-209 (in Persian with English summary).

[11] Mekki, B. E. D. (2016): Effect of weed control treatments and potassium fertilization on root yield and quality of sugar beet under water stress conditions. - American-Eurasian Journal of Agriculture and Environmental Science 16(6): 1135-1143. 
[12] Morishita, D. W. (2003): Herbicides for weed control in sugar beets. - Extension Services of University of Idaho, Oregon State University, and Washington State University, pp. 1-11.

[13] Parker, C., Riches, C. R. (1993): Parasitic Weeds of the World: Biology and Control. CAB Int., Wallingford, UK, pp. 333-339.

[14] Petersen, J. (2004): A Review on Weed Control in Sugar Beet. - In: Inderjit (ed.) Weed Biology and Management. Springer, Dordrecht, pp. 467-483.

[15] Sarić-Krsmanović, M., Vrbničanin, S. (2017): Field dodder life cycle and interaction with host plants. - Pesticidi i Fitomedicina. 32(2): 95-103.

[16] Sarić-Krsmanović, M., Božić, D., Malidža, G., Radivojević, L., Gajić-Umiljendić, J., Vrbničanin, S. (2015): Chemical control of field dodder in alfalfa. - Pesticidi i Fitomedicina 30(2): 107-114.

[17] Sohrabi, M., Ghalavand, A., Rahimian, H., Fatuhi, K. (2001): Chemical control of dodder (Cuscuta campestris) in sugar beet and evaluation of phytotoxicity effects on wheat in rotation. - Iran Journal of Crop Science 3: 26-33 (in Persian with English summary).

[18] Vasel, E. H., Ladewig, E., Märländer, B. (2012): Weed composition and herbicide use strategies in sugar beet cultivation in Germany. - Journal of Cultivated Plants 64(4): 112125.

[19] Weinberg, T., Lalazar, A., Rubin, B. (2003): Effects of bleaching herbicides on field dodder (Cuscuta campestris). - Weed Science 51(5): 663-670.

[20] Zimdahl, R. L. (1980): Weed-Crop Competition: A Review. - International Plant Protection Centre, Oregon State University, Corvallis.

[21] Ziveh, P. S., Fadakar, F., Mahdavi, V. (2013): Chemical control of dodder (Cuscuta spp.) in the sugar beet fields. - Technical Journal of Engineering and Applied Sciences 3(24): $3502-3505$. 